\title{
Rotan Potensial dari Hutan Bukit Lubuk Pekak, Merangin, Jambi
}

\author{
Titi Kalima ${ }^{1 *}$, Ratih Damayanti ${ }^{2}$, Adi Susilo ${ }^{1}$ \\ 1) Pusat Penelitian dan Pengembangan Hutan, Jl.Gunung Batu No. 5 PO Box 165, Bogor, West Java, Indonesia \\ Telp.0251-8633234; Fax 0251-863111 \\ 2) Pusat Penelitian dan Pengembangan Hasil Hutan, Jl.Gunung Batu No.5, Bogor 16610, Bogor, West Java, Indonesia \\ Telp.0251-8633378; Fax 0251-8633413 \\ *Corresponding author, email: titi_kalima@yahoo.co.id
}

\section{Keywords: \\ rattan \\ diversity \\ exploration \\ Bukit Lubuk Pekak \\ Jambi}

\section{Article history: \\ Submitted 08/11/2018 \\ Revised 07/02/2019 \\ Accepted 29/03/2019}

\begin{abstract}
Rattan is a potential non-timber forest product. It grows in almost parts of Indonesia and has been widely used and traded. Indonesia as the largest rattan producer in the world supplies about $85 \%$ of world rattan needs. However, the threat from rattan exploitation is increasing, especially in Bukit Lubuk Pekak. Bukit Lubuk Pekak Forest is part of Production Forest Management Unit (KPHP) area located in Merangin District, Jambi Province. It is necessary to conduct study on the potency of rattan in that area for future conservation efforts. This study aimed to investigate rattan species in Bukit Lubuk Pekak forest, Merangin District, Jambi Province. Information of the potency of rattan is essential to support rattan industries. To complete data of rattan potency from Sumatra, an exploration in this area was carried out in July 2016 in Bukit Lubuk Pekak Forest. The study was conducted by purpossive sampling. Identification on morphological characteristics of rattan were performed on all parts of plants including fruits and seeds (if available). The results showed that there were four rattan genera in Bukit Lubuk Pekak Forest: Calamus, Daemonorops, Korthalsia, and Plectocomiopsis. They consisted of nine species, namely Calamus caesius, C. exillis, C. insignis var. longispinosus, C. laevigatus, C. tumidus, Daemonorops micracantha, D. didymophylla, Korthalsia flagellaris, and Plectocomiopsis geminiflora. Among the nine species, two species that is Calamus caesius and Daemonorops didymophylla have been cultivated for industry raw materials and medicine, respectively.
\end{abstract}

\section{PENDAHULUAN}

Hutan Bukit Lubuk Pekak, merupakan salah satu wilayah Kesatuan Pengelolaan Hutan Produksi (KPHP) Model di Kabupaten Merangin, yang ditetapkan berdasarkan Keputusan Menteri Kehutanan Republik Indonesia Nomor : SK.43/ Menhut-II/2012 tanggal 2 Februari 2012 dengan luas \pm 9.944 ha. Salah satu karakteristik kawasan hutan Bukit Lubuk Pekak adalah keanekaragaman jenis rotan. Namun, belum ada penelitian secara khusus yang mengeksplorasi jenis-jenis rotan di wilayah KPHP tersebut.

Rotan merupakan tumbuhan serba guna dalam suku Arecaceae yang tumbuh secara alami di lantai hutan pada berbagai tipe hutan mulai dari dataran rendah sampai dengan dataran tinggi. Ciri-ciri umum rotan yaitu berupa tumbuhan berhabitus semak, berduri dan buahnya bersisik dengan sifat tumbuh merayap, menjalar, atau memanjat pada tegakan pohon. Secara alami, rotan mempunyai bentuk yang khas, unik, eksotik dan juga sudah dikenal oleh masyarakat Indonesia dalam berbagai keperluan hidup sehari-hari (Kusnaedi \& Pramudita, 2013), seperti untuk menjadikannya sebagai penampilan artistik yang ramah lingkungan (Rachman \& Jasni, 2013). Berbagai pemanfaatan rotan sebagai sumber pangan, sumber minuman, bahan dasar obat dan kosmetik, bahan kerajinan rumah tangga, bahan bangunan, dan bahan baku mebel untuk mendukung industri rotan (Ariana, et al., 2011; Kalima \& Susilo, 2015).

Indonesia merupakan salah satu negara yang berada di kawasan khatulistiwa dengan keanekaragaman makhluk hidup yang melimpah di 
dunia. Tumbuhan rotan (Arecaceae) hampir ditemui di seluruh wilayah Indonesia. Terdapat 314 jenis tumbuhan rotan yang termasuk dalam delapan (8) genus meliputi genus Calamus (204 sp.), Ceratolobus (7 sp.), Daemonorops (71 sp.), Korthalsia (19 sp.), Myrialepis (1 sp.), Plectocomia (6 sp.), Plectocomiopsis (4 sp.) dan Pogonotium (2 sp.), yang menempati wilayah Indonesia dan baru sekitar 62 jenis rotan yang merupakan jenis komersial atau laku diperdagangkan karena sifatnya sudah dikenal ataupun belum dikenal Jasni et al., 2007; 2010; 2012; 2017; Rachman \& Jasni, 2013; Kalima, 2018 (data belum dipublikasikan)). Sekitar 85 persen bahan baku rotan di seluruh dunia dihasilkan oleh Indonesia (Retraubun, 2013), sehingga rotan menjadi produk Hasil Hutan Bukan Kayu (HHBK) terpenting di dunia (Schreer, 2016).

Mengingat potensi rotan yang sangat beragam bagi kehidupan manusia, maka penelitian ini menarik untuk dilakukan. Untuk itu, dilakukan penelitian dan pengembangan bagi keanekaragaman jenis rotan dan menggali potensi pemanfaatan rotan di hutan Bukit Lubuk Pekak berdasarkan tinjauan sifat dasar rotan, sehingga dapat diketahui peruntukan dan kualitas secara lebih tepat untuk setiap jenisnya. Dengan demikian diharapkan kebutuhan akan jenis-jenis rotan tercapai dan kelestarian jenis terjamin.

\section{BAHAN DAN METODE}

\section{Waktu dan Lokasi Penelitian}

Penelitian dilakukan pada bulan Juli 2016 di Kabupaten Merangin, Jambi yaitu di kawasan hutan Kesatuan Pengelolaan Hutan Produksi (KPHP) Model Bukit Lubuk Pekak, Desa Beringin Sanggul, Kecamatan Merangin, Kabupaten Merangin, Provinsi Jambi. Lokasi penjelajahan jenis rotan terdapat di blok pemanfaatan HHBK dan blok pemungutan HHBK (Gambar 1). Secara geografis terletak antara $101^{\circ} 54^{\prime} 37,80^{\prime \prime}-102^{\circ} 23^{\prime} 29,50^{\prime \prime}$ BT dan $02^{\circ} 20^{\prime} 05,86^{\prime \prime}-02^{\circ} 46^{\prime} 21,61^{\prime \prime}$ LS. Topografi di wilayah Bukit Lubuk Pekak didominasi perbukitan sampai pegunungan. Kondisi lokasi penelitian curam dengan kelas kelerengan 25-70\%. Ketinggian lokasi dari permukaan laut $800-1.900 \mathrm{~m}$. Tipe iklim B dengan jenis tanah podsolik, latosol, andosol, komplek latosol, litosol, dan regusol (Dinas Kehutanan Jambi, 2008).

\section{Alat dan Bahan}

Alat dan bahan yang diperlukan untuk proses koleksi, identifikasi jenis, pembuatan herbarium, dan pengolahan rotan mentah sebagai berikut:

1. Koleksi. Alat dan bahan yang digunakan adalah: keanekaragaman jenis-jenis rotan yang tumbuh di kawasan hutan Bukit Lubuk Pekak, Kabupaten
Merangin, Provinsi Jambi, peta KPHP Model Kabupaten Merangin, GPS (global positioning system), karung $100 \mathrm{~kg}$, kompas, gunting ranting, teropong, meteran dan kaliper, ransel, tali rafia, alat tulis, golok/parang, alkohol 70\% atau spiritus, kertas koran, etiket gantung (label herbarium), kantong plastik ukuran $60 \times 40 \mathrm{~cm}$, dan lain lain. Dalam hal ini diperlukan pula perahu motor sebagai sarana transportasi menuju lokasi kawasan KPHP Merangin, khususnya di hutan Bukit Lubuk Pekak.

2. Identifikasi. Alat yang digunakan adalah: lensa pembesar, data pengamatan (tally sheet) jenis rotan biasanya masih menggunakan nama lokal/daerah setempat, spesimen koleksi herbarium, dan buku acuan identifikasi.

3. Pembuatan herbarium. Alat dan bahan yang diperlukan dalam pembuatan herbarium kering yang diperlukan adalah: kertas koran, tali, gunting, pisau, sasak (pengepres spesimen herbarium), oven, kertas acid free (koleksi), label herbarium, amplop herbarium, etiket herbarium, lem/selotip bening (M3), dan ekologi.

4. Pengolahan rotan mentah. Alat dan bahan yang digunakan adalah bak penggorengan rotan, bak pencucian rotan, alat pengering rotan, ruang pengasapan rotan (asap belerang).

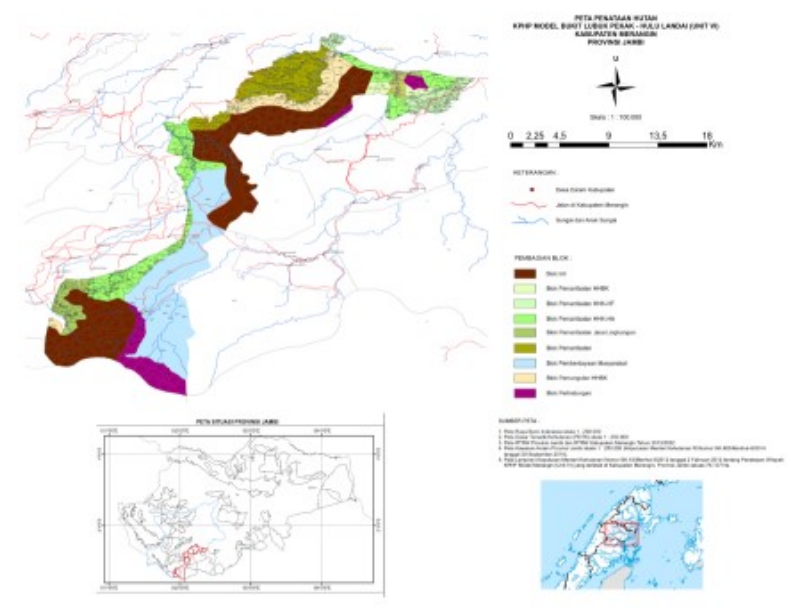

Gambar 1. Lokasi penelitian jenis rotan terdapat pada blok pemanfaatan dan pemungutan HHBK di KPHP Model Bukit Lubuk Pekak, Merangin, Jambi

\section{Metode Lapangan}

Penelitian ini merupakan penelitian deskriptif eksploratif. Metode yang digunakan adalah metode jelajah (Cruising methods) melalui tahapan sebagai berikut :

1. Melakukan eksplorasi jenis-jenis rotan dengan menjelajahi hutan Bukit Lubuk Pekak.

2. Mengumpulkan data botani dengan pengamatan terhadap variabel ciri-ciri morfologi habitus tumbuhan rotan secara purposif berdasarkan pengetahuan masyarakat setempat tentang 
Tabel 1. Jenis-jenis rotan pada kawasan hutan Bukit Lubuk Pekak, KPHP Kabupaten Merangin, Provinsi Jambi.

\begin{tabular}{llll}
\hline No & Nama daerah/lokal & Marga & Jenis \\
\hline 1 & Rotan sego & Calamus & C. caesius Blume \\
2 & Rotan paku & & C. exillis Griff. \\
3 & Rotan buruk ati & & C. insignis var. Longispinosus J. Dransf. \\
4 & Rotan tunggal & C. laevigatus Martius \\
5 & Rotan sijau & C. tumidus Furtado \\
6 & Rotan getah & Daemonorops & D. micracantha (Griff.) Beccari \\
7 & Rotan duduk & & D. didymophylla Beccari \\
8 & Rotan udang & Korthalsia & K. flagellaris Miquel \\
9 & Rotan opon & Plectocomiopsis & P. geminiflora (Griff.) Beccari \\
\hline
\end{tabular}

keberadaan jenis-jenis rotan. Semua data yang diperoleh dicatat dalam tally sheet seperti tanggal dan tempat koleksi, nomor koleksi, tempat tumbuh, nama kolektor, nama marga, nama daerah/ nama lokal serta catatan khusus dalam hal warna.

3. Mengambil contoh spesimen guna pembuatan herbarium basah di lapangan dengan mengikuti standar yang sudah baku secara internasional (steril dan fertil) untuk bahan identifikasi (Kalima, 2014).

4. Mengumpulkan batang rotan dilakukan pada tumbuhan rotan yang sudah masak tebang.

5. Rotan besar dipotong sepanjang 3-4 $\mathrm{m}$ dan rotan kecil dipotong sepanjang kurang lebih $6 \mathrm{~m}$ (Rachman \& Jasni, 2013). Batang rotan kemudian diikat menjadi bundelan yang siap dikirim ke Laboratorium Anatomi Puslitbang Hasil Hutan, Bogor, untuk dianalisis.

6. Mengidentifikasi spesimen herbarium. Jenis rotan yang sudah dikenal langsung ditentukan nama ilmiah atau nama botaninya, sedangkan spesimen herbarium yang belum diketahui nama ilmiahnya dibawa atau dikirim ke Laboratorium Herbarium Botani dan Ekologi Hutan, Puslitbang Hutan, Bogor, untuk dilakukan identifikasi.

7. Melakukan dokumentasi jenis-jenis rotan yang terkoleksi berdasarkan data lapangan.

\section{Metode Laboratorium}

Keanekaragaman spesimen herbarium jenis rotan yang sudah terkoleksi dan belum diketahui ketepatan nama ilmiahnya, terlebih dahulu dilakukan pemrosesan kering spesimen herbarium di laboratorium (Kalima, 2014).

\section{Analisa Data}

Spesimen herbarium yang sudah kering diidentifikasi untuk mendapatkan nama ilmiahnya. Untuk mengetahui nama ilmiah digunakan metode komparatif dengan spesimen herbarium yang sudah diidentifikasi dan dikoleksi di Laboratorium Herbarium Botani dan Ekologi Hutan, Puslitbang Hutan, Bogor. Identifikasi dengan melakukan pengamatan karakter-karakter pembeda jenis pada rotan komersil Sumatera antara lain: habitus, diameter batang, kedudukan duri pada pelepah daun, serta perbungaan dan perbuahannya; melakukan pengamatan pada koleksi spesimen herbarium di laboratorium Botani dan Ekologi Hutan, Puslitbang Hutan, Bogor sebagai pembanding serta pelaku industri rotan di Jambi khususnya dan Sumatera pada umumnya. Selain itu, identifikasi jenis-jenis rotan juga mengacu pada pustaka-pustaka: Dransfield (1979, 1992), Dransfield \& Manokaran (1996), Dransfield et al. (2008), serta beberapa penelitian rotan di Indonesia seperti: Kalima (2008), Kalima \& Jasni (2015), Witono et al. (2013). Hasil identifikasi spesies rotan ditampilkan dalam bentuk deskripsi jenis, dilengkapi dengan foto, data lokasi pengambilan sampel, dan keterangan pemanfaatannya oleh masyarakat setempat.

\section{HASIL DAN PEMBAHASAN}

Berdasarkan hasil identifikasi diperoleh sembilan jenis rotan potensial dalam empat marga yang dikoleksi dari hutan Bukit Lubuk Pekak, Merangin, Jambi. Keempat marga rotan yaitu Calamus, Daemonorops, Korthalsia, dan Plectocomiopsis, disajikan pada Tabel 1.

Pengamatan terhadap ciri-ciri morfologi sampel jenis rotan pada Tabel 1 di atas menunjukkan bahwa kesembilan jenis rotan tersebut memiliki karakteristik habitus, daun, pelepah daun, buah dan ciri lainnya yang secara jelas dapat digunakan untuk mengenali perbedaan antar jenis. Perbedaan morfologi yang jelas diantara kesembilan jenis tersebut sangat bermanfaat dalam mengenali perbedaan antar sampel rotan di lapangan.

Selain sifat morfologi, keanekaragaman jenis rotan yang ditemukan di lokasi penelitian diduga disebabkan oleh bentang alam tempat tumbuhan itu hidup. Menurut Fatchan (2013), bentang alam memiliki berbagai macam struktur bentuk bumi yang tercakup dalam relief muka bumi. Dilihat dari lokasi tempat tumbuh, wilayah kawasan hutan Bukit Lubuk Pekak merupakan gunung, perbukitan, lembah, dataran rendah, dan dataran tinggi sehingga memungkinkan keanekaragaman jenis rotan di 
daerah tersebut relatif sedikit yaitu 9 jenis. Hal ini juga dipengaruhi faktor lingkungan yang lain dari jenis tumbuhan yang hidup di sekitar tumbuhan rotan serta faktor suhu, kelembaban udara, intensitas cahaya dan $\mathrm{pH}$ tanah terhadap pertumbuhan rotan itu sendiri, seperti yang dilaporkan oleh Kalima (2008) bahwa rotan dapat tumbuh subur di berbagai tempat, baik dataran rendah maupun agak tinggi, terutama di daerah yang lembab.

Pertelaan, persebaran, dan kualitas batang rotan seperti yang disajikan pada Tabel 1 sebagai berikut:

\section{Calamus caesius Blume}

Nama daerah: Rotan sego (Jambi), rotan sega (Sumatera, Borneo).

Tumbuh berumpun, diameter dengan pelepah 25 $\mathrm{mm}$, diameter tanpa pelepah 7-12 $\mathrm{mm}$, panjang ruas $15-50 \mathrm{~cm}$. Pelepah daun terdapat indumentum berwarna keputihan, berduri segitiga pipih, panjang duri $0,2-0,5 \mathrm{~cm}$, warna duri coklat kehitaman. Lutut tidak berduri. Okrea tidak jelas. Panjang daun 75 $\mathrm{cm}$, panjang sirus $75 \mathrm{~cm}$, panjang tangkai $1 \mathrm{~cm}$ atau hampir tidak bertangkai. Permukaan atas anak daun berwarna hijau mengkilap, bagian bawah anak daun berwarna putih kapur, anak daun bagian pangkal memeluk batang. Perbungaan jantan bercabang tiga tingkat, sedangkan pada yang betina hanya dua tingkat. Buah bulat telur, berukuran $15 \times 10 \mathrm{~mm}$, ditutupi sisik vertikal berjumlah 15-21. Buah masak berwarna coklat kekuning-kuningan.

Persebaran: Sumatera, Kalimantan, Filipina, dan Thailand, ditemukan di semua tipe hutan, bahkan di hutan rawa. Hasil penelitian sifat dasar dan pemanfaatan rotan menunjukkan bahwa jenis Calamus caesius ditemukan di Kalimantan Selatan, Barat, dan Tengah (Jasni et al. 2010; Kalima \& Sumarhani, 2015).

Kualitas batang: batang kualitas sangat bagus termasuk Kelas 1 (Jasni et al., 2010).

\section{Calamus exillis Griff.}

Nama daerah: Rotan paku (Sumatera).

Tumbuh berumpun, diameter dengan pelepah antara 6-10 mm, diameter batang tanpa pelepah daun 4-8 $\mathrm{mm}$. Pelepah daun berwarna coklat-kelabu dan kusam. Lutut jelas. Panjang flagela 1,75 m. Panjang daun $60 \mathrm{~cm}$, tangkai $30 \mathrm{~cm}$. Helaian anak daun 22-40 pasang, tersusun menyirip teratur, bentuk pita melanset, berukuran 40 x $2 \mathrm{~cm}$, permukan atasnya berbulu lebat. Tidak ditemukan bunga dan buah (Steril).

Persebaran: hanya tumbuh di Semenanjung Malaya dan Sumatera; hampir ditemukan di semua tipe hutan, bahkan di hutan rawa, pada ketinggian sampai $1000 \mathrm{~m} \mathrm{dpl}$.
Kualitas batang: kualitas batang bagus; karena berdiameter kecil sangat cocok untuk tali dan bahan anyaman (Jasni et al. 2017).

\section{Calamus insignis Griff. var. longispinosus Dransfield}

Nama daerah: Rotan buruk ati (Jambi), rotan batu (Sumatera Utara).

Tumbuh tunggal, diameter dengan pelepah $18 \mathrm{~mm}$, tanpa pelepah daun $10 \mathrm{~mm}$. Pelepah daun berwarna hijau kusam sampai terang, ditutupi duri tunggal hijau dengan ujung hitam dan rapat, panjang duri 2,5-3 cm. Lutut jelas, berduri. Panjang flagela $150-212 \mathrm{~cm}$. Panjang daun $47-57 \mathrm{~cm}$, hampir tidak bertangkai. Helaian anak daun tersusun berpasangan teratur, berjumlah 9 pada sisi rakis, anak daun bagian pangkal memeluk batang, ukuran helaian anak daun 9-28 $\mathrm{cm} \times 2,5-10 \mathrm{~cm}$. Tidak ditemukan bunga dan buah (Steril).

Persebaran: Jambi (Bukit Lubuk Pekak, Merangin), Sumatera Utara, Kalimantan, Malay Peninsula (Kedah, Perak, Pahang, Selangor, Trenggano, Negeri Sembilan), di tanah kering, perbukitan pada ketinggian $1000 \mathrm{~m}$ di atas permukaan laut

Kualitas batang: kualitas batang sangat bagus, mempunyai berat jenis tertinggi $(B J=0,73)$ termasuk Kelas I (Puslitbang Hasil Hutan, 2017). Jenis ini dikenal di pasar dengan nama sebagai rotan batu. Karena berdiameter kecil, secara luas rotan ini digunakan oleh Orang Asli sebagai bahan pengikat dan untuk keranjang halus. Batang mempunyai warna alami abu-abu dan sangat diminati para pengrajin.

\section{Calamus laevigatus Martius}

Nama daerah: Rotan tunggal (Jambi), rotan tunggal (Sumatera, Borneo).

Tumbuh tunggal, diameter batang dengan pelepah $20 \mathrm{~mm}$, tanpa pelepah daun $8-10 \mathrm{~mm}$, panjang ruas mencapai $25 \mathrm{~cm}$. Pelepah daun berwarna hijau, hampir tidak berduri, kalau berduri hanya pendek dan jarang. Lutut jelas. Panjang daun $60-100 \mathrm{~cm}$, panjang tangkai $3 \mathrm{~cm}$ atau hampir tidak bertangkai, bersirus panjang $1 \mathrm{~m}$. Helaian anak daun berjumlah 33 pada sisi rakis, anak daun bagian pangkal memeluk batang, susunan anak daun menyirip teratur dan ada yang tidak teratur, panjang anak daun antara $15-23 \mathrm{~cm}$, dan lebar anak daun $1 \mathrm{~cm}$. Tidak ditemukan bunga dan buah (Steril).

Persebaran: Jambi (Bukit Lubuk Pekak, Merangin), Kalimantan, Malay Peninsula (Kedah, Perak, Pahang, Selangor, Trenggano, Negeri Sembilan), Singapore, pada tanah kering, perbukitan pada ketinggian $800 \mathrm{~m}$ di atas permukaan laut.

Kualitas batang: kualitas batang bagus, mempunyai berat jenis tinggi $(B J=0,72)$. Keawetan terhadap 
bubuk termasuk Kelas I. Ketahanan terhadap rayap tanah termasuk Kelas II (Puslitbang Hasil Hutan, 2017). Karena memiliki diameter kecil, rotan ini digunakan untuk bahan pengikat, keranjang halus, dan tikar.

Hasil penelitian Kalima dan Sumarhani (2015) melaporkan bahwa jenis C. laevigatus juga ditemukan di dataran rendah di hutan Tumbang Liting, Kecamatan Katingan Hilir, Kabupaten Katingan, Kalimantan Tengah, dengan nama daerah kulus.

\section{Calamus tumidus Furtado}

Nama daerah: sijau (Jambi), manau tikus (Sumatera). Tumbuh tunggal, diameter batang dengan pelepah $45 \mathrm{~mm}$, tanpa pelepah daun $12 \mathrm{~mm}$ pada bagian pangkal dan $25 \mathrm{~mm}$ pada bagian atas. Panjang ruas bagian atas mencapai $12 \mathrm{~cm}$, bagian bawah $30 \mathrm{~cm}$. Pelepah daun waktu muda berwarna coklat kemerahan, berubah hijau kekuning-kuningan, pangkal duri bulat keras, ukuran duri $4 \times 7 \mathrm{~mm}$, duri tersebar atau sedikit berkelompok. Lutut jelas berupa tonjolan. Okrea kecil, kurang jelas. Panjang daun $4 \mathrm{~m}$ termasuk sirus $1,5 \mathrm{~m}$. Panjang tangkai 30 $\mathrm{cm}$, warna coklat kemerahan. Helaian anak daun berjumlah 25 pada tiap sisi rakis, berpasangan. Tidak ditemukan bunga dan buah (Steril).

Persebaran: Sumatera.

Kualitas batang: kualitas batang sangat bagus, mempunyai berat jenis tertinggi $(B J=0,73)$, ketahanan terhadap bubuk termasuk Kelas I. Jenis rotan ini digunakan sebagai pengganti rotan manau dan banyak digunakan untuk kerangka mebel (Jasni \& Kalima 2007).

\section{Daemonorops micracantha (Griff.) Beccari}

Nama daerah: rotan getah (Jambi), rotan jernang (Borneo).

Tumbuh berumpun, diameter batang dengan pelepah $25 \mathrm{~mm}$, tanpa pelepah $12 \mathrm{~mm}$. Pelepah daun berwarna hijau kekuningan, ditutupi indumentum coklat keabu-abuan, berduri dengan ukuran $2 \mathrm{~mm}$. Lutut jelas dengan duri kecil, kadangkadang tidak berduri. Panjang daun $145 \mathrm{~cm}$, tangkai $20 \mathrm{~cm}$, sirus $65 \mathrm{~cm}$. Helaian anak daun berjumlah 72 pada sisi rakis, tersusun menyirip teratur; ukuran helaian anak daun 10-25 $\mathrm{cm} \times 0,5-2$ $\mathrm{cm}$. Buah bulat berukuran $20-25 \mathrm{~mm} \times 18-20 \mathrm{~mm}$, ditutupi 18-22 sisik vertikal.

Persebaran: Sumatera, Borneo, Semenanjung Malaya.

Kualitas batang: batang kurang bagus, mempunyai berat jenis tertinggi 0,42, kualitas termasuk Kelas IV (Puslitbang Hasil Hutan, 2017). Ketahanan terhadap rayap tanah termasuk Kelas III. Batang rotan ini hanya dimanfaatkan secara lokal oleh penduduk setempat. Batang rotan getah menghasilkan resin merah pada kulit buah rotan (getah jernang) yang digunakan untuk pewarna dan obat-obatan.

\section{Daemonorops didymophylla Beccari}

Nama daerah: Rotan duduk (Jambi), rotan jernang (Sumatera, Borneo)

Tumbuh berumpun, diameter batang dengan pelepah sampai $25 \mathrm{~mm}$, diameter tanpa pelepah sampai $12,5 \mathrm{~mm}$, panjang ruas mencapai $30 \mathrm{~cm}$. Pelepah daun berwarna hijau tua,berduri mengelompok, kadang-kadang merata. Duri berwarna abu-abu sampai hitam, panjang antara 0,4$2,5 \mathrm{~cm}$, bagian pangkal kuning. Lutut tampak jelas. Panjang daun mencapai $270 \mathrm{~cm}$, panjang tangkai daun hingga $35 \mathrm{~cm}$, dan panjang sirus hingga 100 $\mathrm{cm}$. Helaian anak daun berjumlah hingga 20 di tiap sisi rakis, tersusun menyilang berhadapan, kadang kadang teratur, ukuran sampai $35 \times 3,5 \mathrm{~cm}$, berambut di sepanjang tepinya. Perbungaan pendek sampai $20 \mathrm{~cm}$, perbungaan jantan dan betina biasanya sama, pada percabangan pertama segera luruh pada saat antesis. Tangkai perbungaan dan cabang pertama berduri dengan sebagian membentuk kelompok, duri sampai $0,5 \mathrm{~cm}$, rakila dan bunga tertutup oleh bulubulu halus berwarna merah kecoklatan. Buah ovoid, ukuran sampai $2,5 \times 2 \mathrm{~cm}$.

Persebaran: Sumatera, Borneo, Semenanjung Malaya, Thailand bagian selatan.

Kualitas batang: kualitas batang sangat bagus, mempunyai berat jenis tertinggi 0,73; kualitas termasuk Kelas I.

\section{Korthalsia flagellaris Miquel}

Nama daerah: Rotan udang (Jambi), rotan dahan (Sumatera, Borneo).

Tumbuh berumpun, batang bercabang, diameter batang dengan pelepah $25 \mathrm{~mm}$, diameter tanpa pelepah $12,5 \mathrm{~mm}$, panjang ruas sampai $25 \mathrm{~cm}$. Pelepah daun berwarna hijau kecoklatan, tertutup oleh bintik-bintik berwarna hitam dan bulu-bulu halus berwarna coklat. Selaput bumbung menempel rapat pada batang. Lutut tidak ada. Panjang daun $98 \mathrm{~cm}$, panjang tangkai $15 \mathrm{~cm}$, panjang sirus $135 \mathrm{~cm}$. Helaian anak daun 11-12 di tiap sisi rakis (tulang daun), bentuk belah ketupat menyempit, ukuran sampai $25 \times 5 \mathrm{~cm}$. Permukaan atas berwarna hijau, permukaan bawah hijau kecoklatan. Tidak ditemukan bunga dan buah (steril).

Persebaran: Sumatera, Borneo, Belitung, Semenanjung Malaya.

Kualitas batang: kualitas batang kurang bagus, mempunyai berat jenis rata-rata 0,43 termasuk Kelas IV. Ketahanan terhadap rayap tanah termasuk Kelas II (Puslitbang Hasil Hutan, 2017). Batang rotan ini hanya dimanfaatkan secara lokal oleh penduduk setempat. 


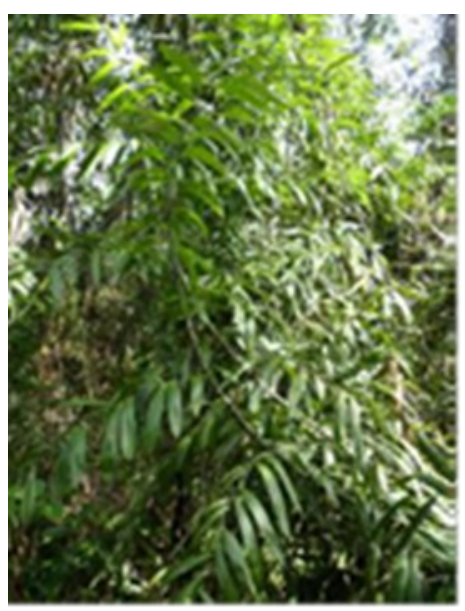

a

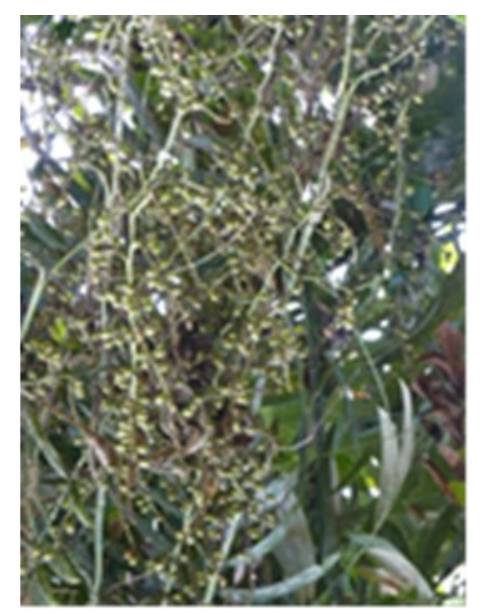

b

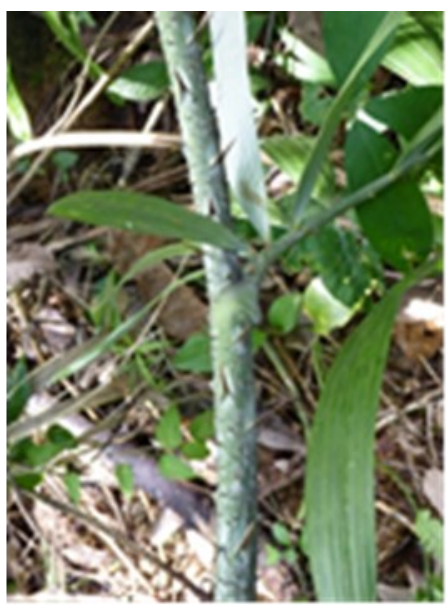

c

Gambar 2. Calamus caesius: (a) habitus; (b) buah; (c) pelepah daun.

(Foto: 'T. Kalima, 2016 Bukit Lubuk Pekak, Jambi)

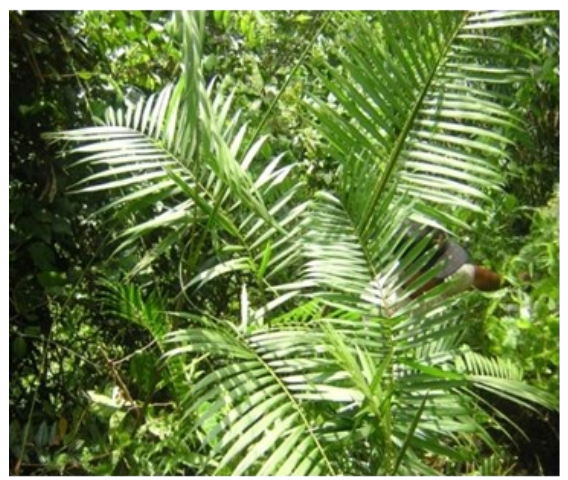

a

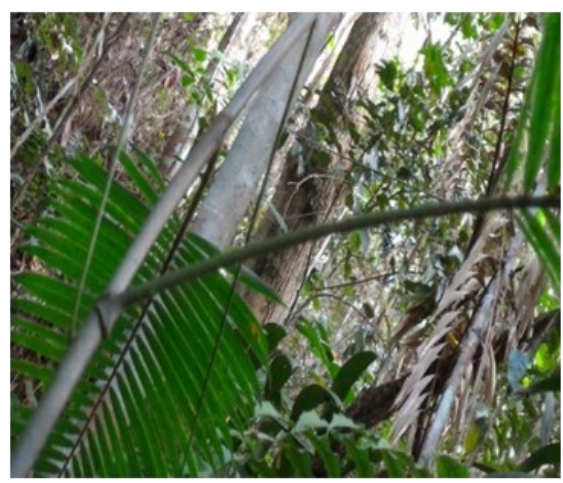

b

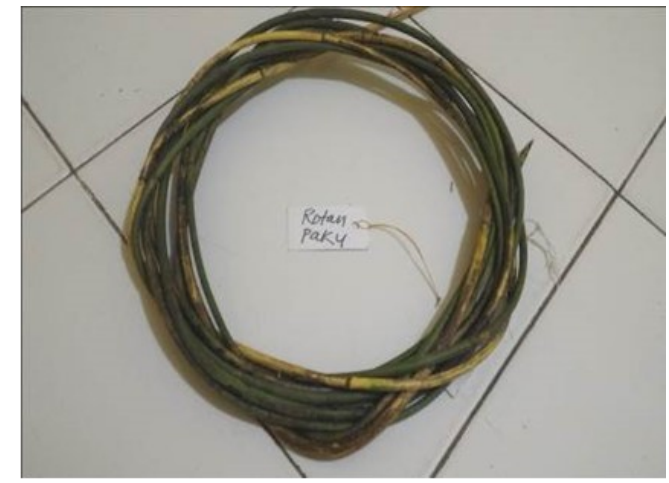

C

Gambar 3. Calamus exillis: (a) habitus; (b) pelepah daun; (c) batang rotan

(Foto: T.Kalima, 2016 Bukit Lubuk Pekak, Jambi)

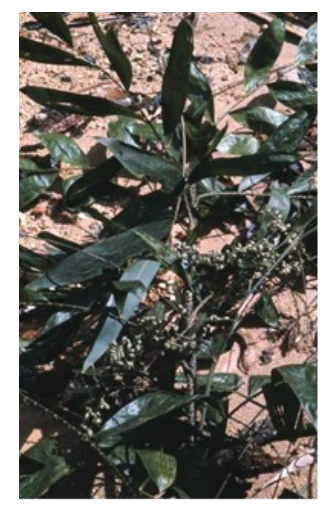

a

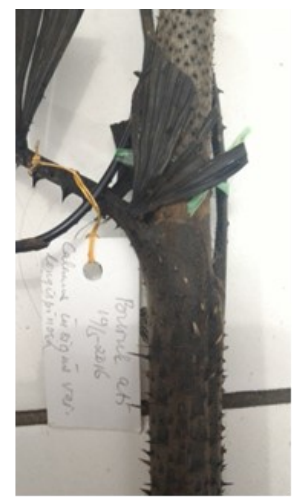

b

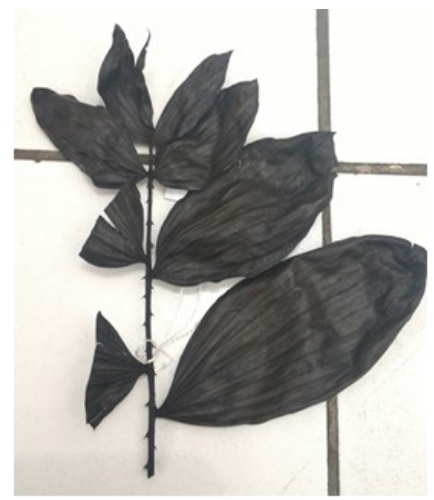

c

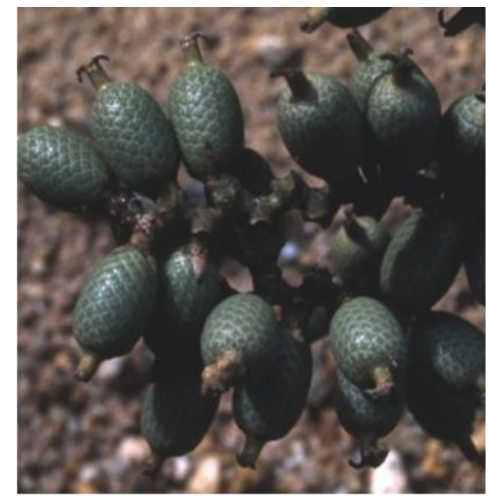

d

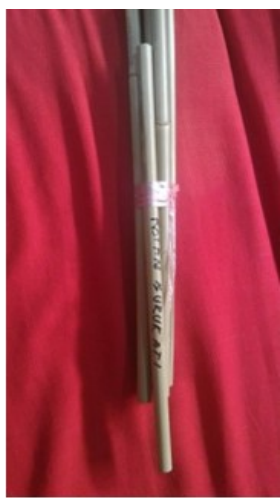

e

Gambar 4. Calamus insignis. var.longispinosus: (a) habitus; (b) pelepah daun; (c) seranting daun (Foto T.Kalima, 2016 Bukit Lubuk Pekak, Jambi); (d) buah (http://www.palmweb.org.); (e) batang rotan (Foto Jasni, 2016) 


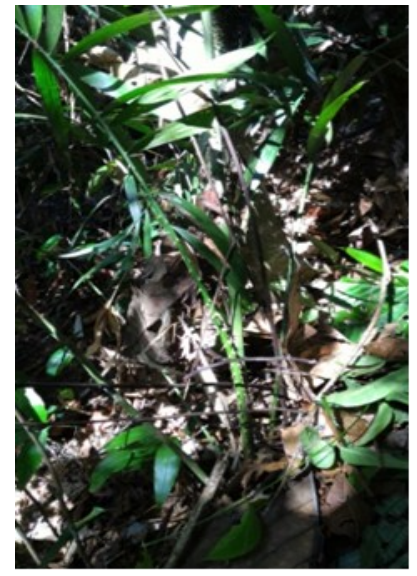

a

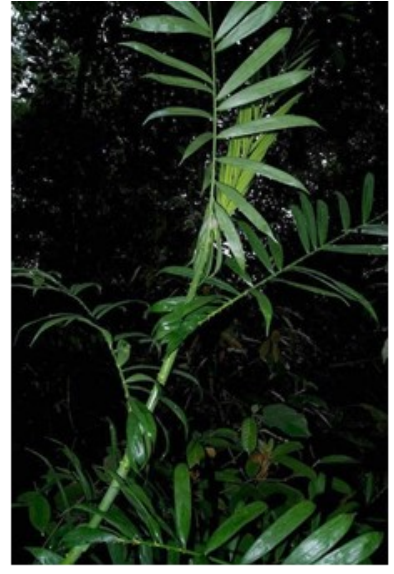

b

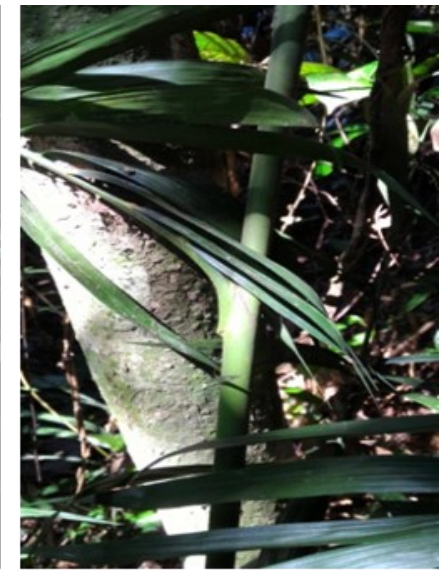

c

Gambar 5. Calamus laevigatus: (a) \& (b) habitus; (c) pelepah daun (Foto: T. Kalima, 2016 Bukit Lubuk Pekak, Jambi)

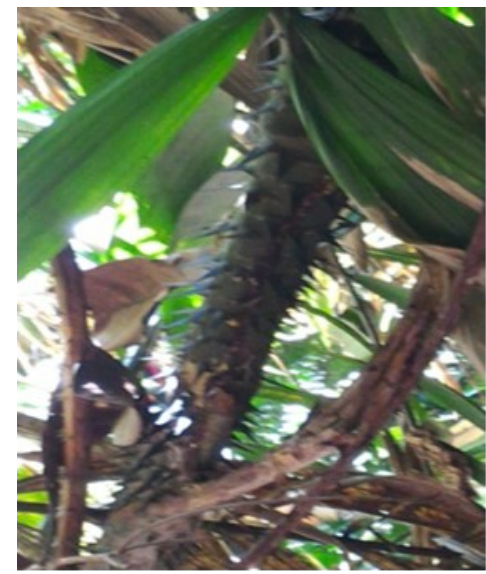

a

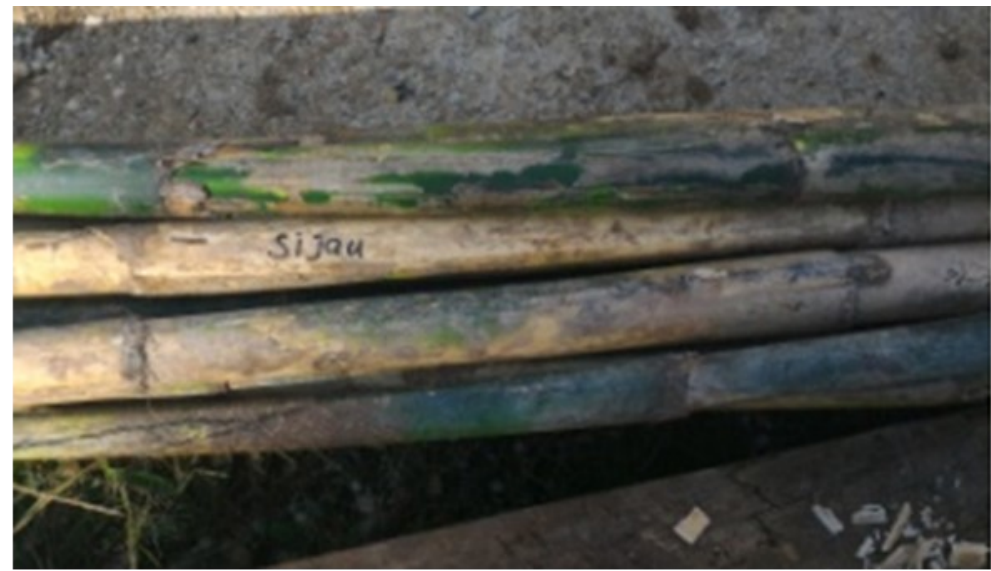

b

Gambar 6. Calamus tumidus: (a) pelepah daun; (b) batang rotan (Foto: T. Kalima, 2016 Bukit Lubuk Pekak, Jambi)

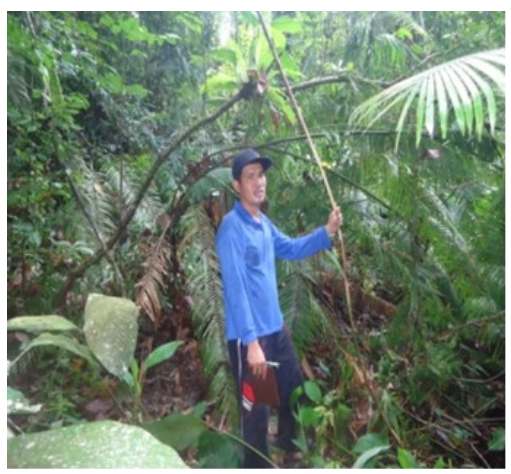

a

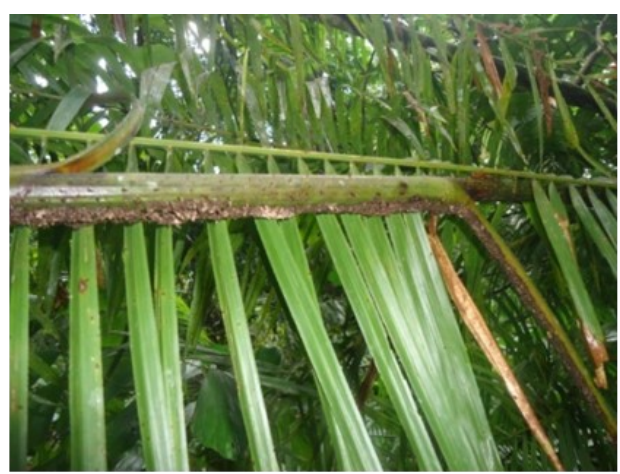

$\mathrm{b}$

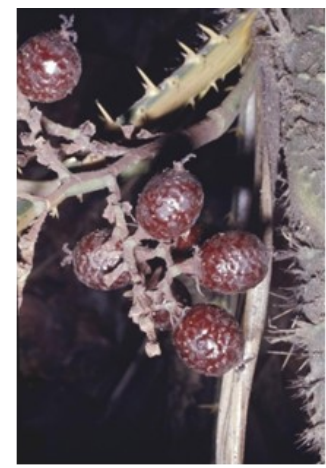

c

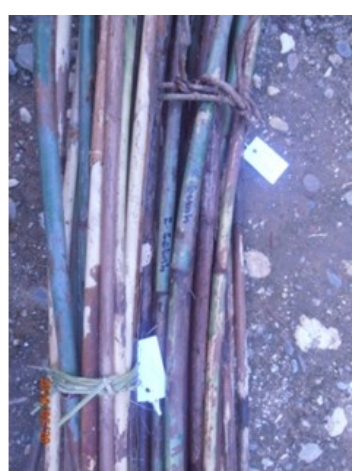

d

Gambar 7. Daemonorops micracantha: (a) batang masak tebang; (b) daun; (c) buah (Foto: Dr. John Dransfield, Royal Botanic Gardens, Kew/Palmweb); (d) batang rotan (Foto: T. Kalima, Bukit Lubuk Pekak, Jambi) 


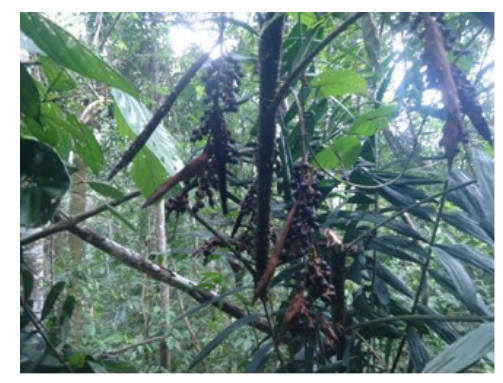

a

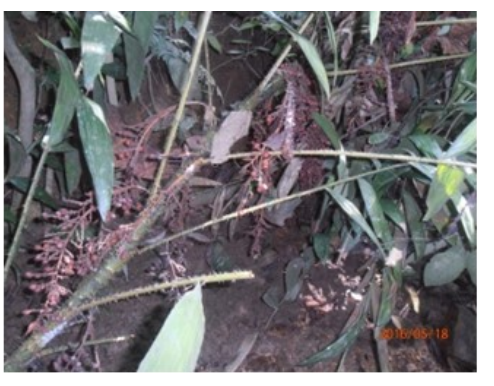

b

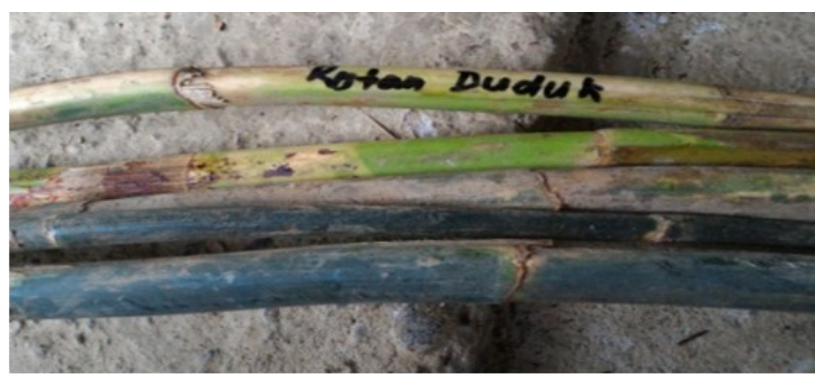

C

Gambar 8. Daemonorops didymophylla: (a) habitus \& buah; (b) pelepah \& buah; (c) buah; (d) batang rotan (Foto: T. Kalima, Bukit Lubuk Pekak, Jambi)

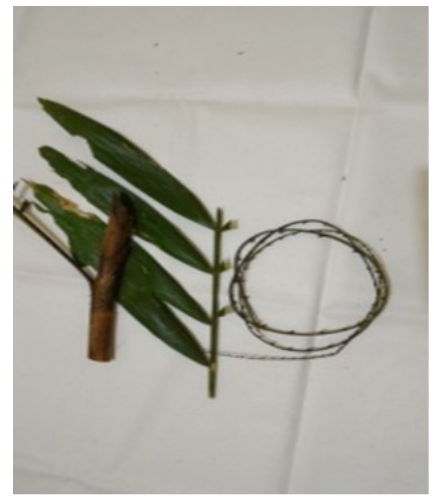

a

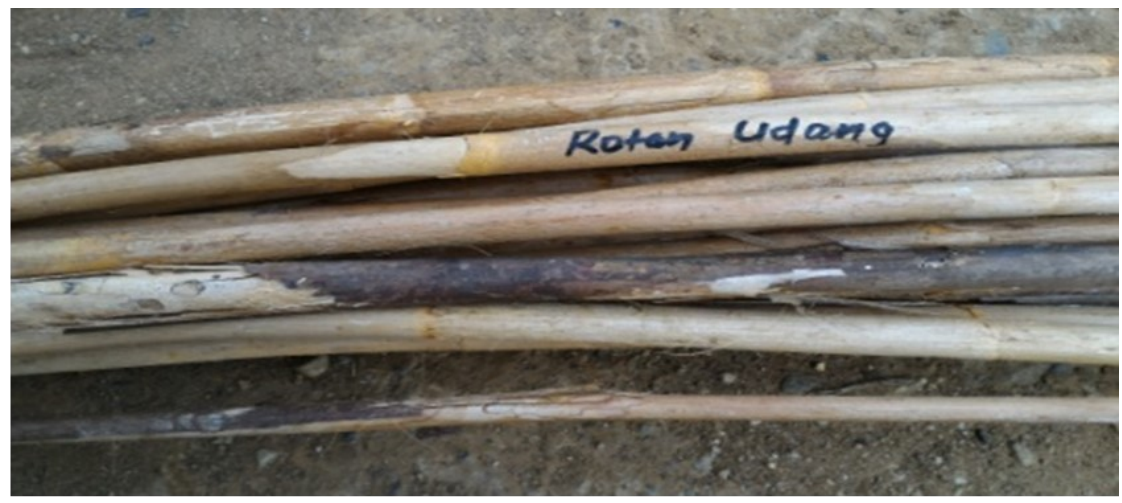

b

Gambar 9. Korthalsia flagellaris: (a) spesimen herbarium; (b) batang rotan (Foto: T. Kalima, 2016. Bukit Lubuk Pekak, Jambi)

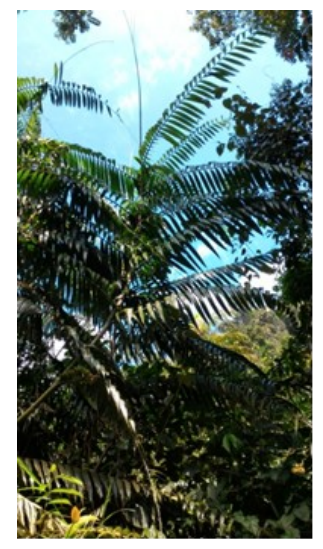

a

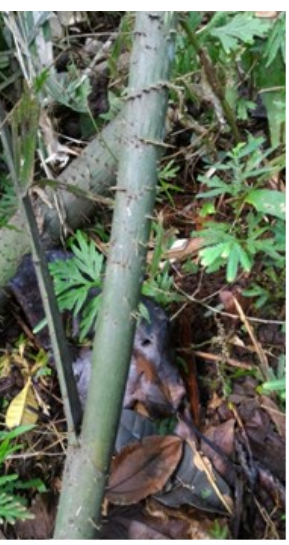

$\mathrm{b}$

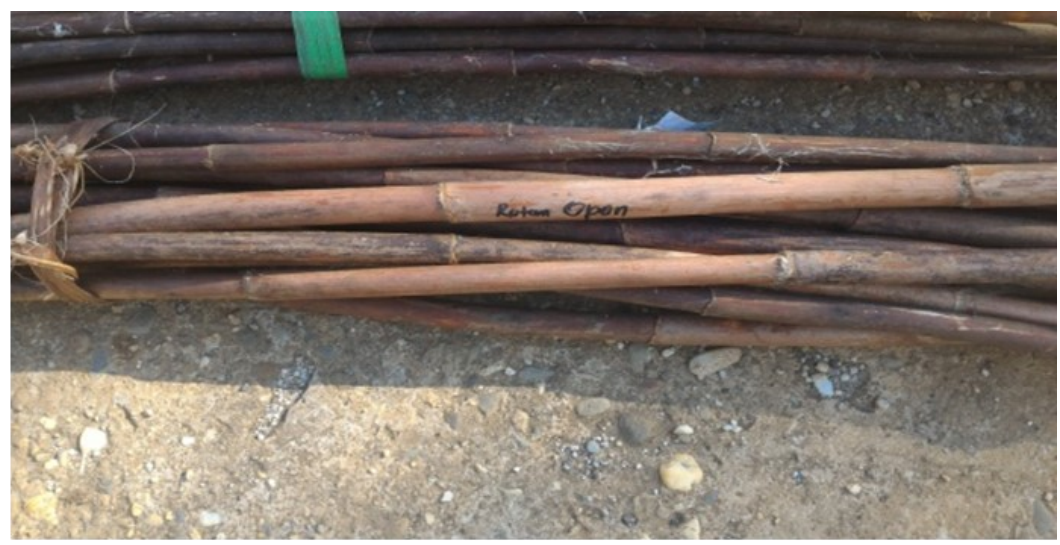

c

Gambar 10. Plectocomiopsis geminiflora: (a) habitus; (b) pelepah daun; (c) batang rotan (Foto: T. Kalima, Bukit Lubuk Pekak, Jambi) 


\section{Plectocomiopsis geminiflora (Griff .) Beccari}

Nama daerah: Rotan opon (Jambi), rotan gilang, rotan rilang (Sumatera, Borneo).

Tumbuh berumpun, diameter batang dengan pelepah daun $35 \mathrm{~mm}$, tanpa pelepah 15-31 mm, panjang ruas $28-38 \mathrm{~cm}$. Pelepah daun berwarna hijau tua, berindumentum coklat keabu-abuan. Lutut tidak ada. Okrea ada. Panjang daun dengan sirus $376 \mathrm{~cm}$, tangkai daun $7 \mathrm{~cm}$. Helaian anak daun berjumlah 28-30 pada satu sisi rakis, tersusun menyirip teratur, berukuran $30-48 \mathrm{~cm} \times 3,5-4,5 \mathrm{~cm}$, bentuk ellips, warna hijau terang berkilau, tulang sekunder jelas berjumlah 5. Tidak ditemukan bunga dan buah (steril).

Persebaran: Sumatera, Borneo, Semenanjung Malaysia dan Thailand Selatan, di hutan primer dipterokarpa dataran rendah, pada berbagai jenis tanah, pada ketinggian sampai 600 meter di atas permukaan laut.

Kualitas batang: kualitas batang bagus, mempunyai berat jenis tertinggi 0,71. Ketahanan terhadap bubuk termasuk Kelas I, ketahanan terhadap rayap tanah termasuk Kelas II.

\section{KESIMPULAN}

Hasil eksplorasi di hutan Bukit Lubuk Pekak, Jambi, ditemukan sembilan jenis rotan yang berasal dari empat marga yaitu Calamus, Daemonorops, Korthalsia, dan Plectocomiopsis. Diantara keempat marga tersebut, C. laevigatus dan C. insignis var. longispinosus merupakan jenis yang tumbuh tunggal (soliter) dengan sebaran paling sedikit dijumpai. Calamus caesius merupkan jenis dengan sebaran paling luas dan paling banyak dijumpai di lokasi penelitian, demikina juga dengan Plectocomiopsis geminiflora. Kesembilan jenis rotan tersebut memiliki keragaman habitus, daun, pelepah, alat panjat, duri, dan buah yang dapat secara jelas digunakan untuk dasar pengenalan/pembedaan antar jenis di lapangan. Pemanfaatan jenis-jenis rotan dari kawasan hutan Bukit Lubuk Pekak masih terbatas pada Plectocomiopsis geminiflora. Daemonorops micracantha dan D. didymophilla merupakan jenis penghasil jernang yang banyak dijumpai hutan-hutan Sumatera. Rotan dari hutan Bukit Lubuk Pekak, Merangin, Jambi sangat berpotensi dikembangkan untuk mendukung industri rotan.

\section{UCAPAN TERIMA KASIH}

Ucapan terima kasih disampaikan kepada Kepala Pusat Litbang Hasil Hutan yang telah menyediakan dana penelitian, Kepala Pusat Litbang Hutan yang telah memberikan perijinan dan fasilitas penelitian, serta kepada para peneliti dan teknisi Herbarium Botani Hutan yang telah membantu dalam mengidentifikasi jenis-jenis rotan, juga kepada staf KPHP Bukit Lubuk Pekak dan para pemandu lapangan di desa Beringin Sanggul, Merangin, Jambi.

\section{ACUAN}

Ariana, G., Noorhidayati \& Aminudin, P.P., 2011, Inventarisasi dan kerapatan tumbuhan palem Suku Palmaceae yang terdapat di kawasan air terjun Hutan Lindung Gunung Gedambaan Desa Gedambaan Kabupaten Kotabaru, Jurnal W ahana-Bio 5: 50-68.

Dinas Kehutanan Jambi, 2008, Rancang Bangun Kesatuan Pengelolaan Hutan Produksi (RbKPHP) Provinsi Jambi.

Dransfield, J., 1979, A Manual of rattans of the Malay Peninsula, Malayan Forest Record No.29, Forest Department, Ministry of Primary Industries Malaysia.

Dransfield. J., 1992, The Rattans of Sarawak, Royal Botanic Gardens, Kew, UK and Sarawak Forestry Department, Kucing, Sarawak, Malaysia.

Dransfield, J. \& Manokaran, N., 1996, Sumber daya nabati Asia Tenggara No. 6, Rotan. Prosea Indonesia. Gajah Mada University Press bekerjasama dengan Prosea Indonesia, Bogor.

Dransfield, J., Uhl, NW., Asmussen, CB., Baker, WJ., Harley, MM. \& Lewis, CE., 2008, Genera Palmarum - the evolution and classification of palms, Royal Botanic Gardens, Kew, Richmond.

Fatchan, A., 2013, Geografi Tumbuban dan Hewan, Penerbit Ombak, Yogyakarta.

Jasni, Damayanti, R. \& Kalima, T., 2007, Atlas Rotan Indonesia, Jilid 1, Badan Penelitian dan Pengembangan Kehutanan Pusat Penelitian dan Pengembangan hasil Hutan, Bogor.

Jasni, Damayanti, R., Kalima, T., Malik, J. \& Abdurachman, 2010, Atlas Rotan Indonesia, Jilid 2, Badan Penelitian dan Pengembangan Kehutanan, Pusat Penelitian dan Pengembangan Keteknikan Kehutanan dan Pengolahan Hasil Hutan, Bogor.

Jasni, Krisdianto, Kalima, T. \& Abdurachman. 2012. Atlas Rotan Indonesia, Jilid 3, Badan Penelitian dan Pengembangan Kehutanan. Pusat Penelitian dan Pengembangan Keteknikan Kehutanan dan Pengolahan Hasil Hutan, Bogor.

Jasni \& Roliadi, H., 2010, Daya tahan 25 jenis rotan terhadap rayap tanah (Coptotermes curvignathus), Jurnal Penelitian Hasil Hutan 28(1): 55-65.

Jasni, Kalima, T., Abdurachman, Krisdianto, Pari, G., Damayanti, R. \& Malik, J., 2017, Atlas Rotan Indonesia, Jilid 4, Badan Penelitian, Pengembangan dan Inovasi, Pusat Penelitian dan Pengembangan hasil Hutan, Bogor. 
Kalima, T., 2008, Keragaman spesies rotan yang belum dimanfaatkan di hutan Tumbang Hiran, Katingan, Kalimantan Tengah, Info Hutan V(2): 161- 175.

Kalima, T., 2014, Panduan Teknis Pengumpulan Herbarium Rotan, Pusat Penelitian dan Pengembangan Konservasi dan Rehabilitasi, Badan Penelitian dan Pengembangan Kehutanan.

Kalima, T. \& Jasni, 2015, Prioritas penelitian dan pengembangan jenis andalan setempat rotan, In A. D. Setyawan, Sugiyarto, A. Pitoyo, U. E. Hernawan, Sutomo, A. Widiastuti, D. Elfidasari (Eds.), Manajemen Perlindungan, Penelitian dan Pemanfaatan Keanekaragaman Hayati di Wilayah Perkotaan, Prosiding Seminar Nasional Masyarakat Biodiversitas Indonesia Vol. 1, pp. 2407-8050.

Kalima, T. \& Sumarhani, 2015, Identifikasi jenisjenis rotan pada hutan rakyat di Katingan, Kalimantan Tengah dan upaya pengembangan, Prosiding Seminar Nasional Masyarakat Biodiversitas Indonesia 1(2): 194-200.

Kalima, T. \& Susilo, A., 2015, The future prospect of rattan as food resources in Central Kalimantan, $6^{\text {th }}$ ICGRC Proceeding Book, ISBN: 2302-108X.
Kusnaedi, I. \& Pramudita, A.S., 2013, Sistem bending pada proses pengolahan kursi rotan di Cirebon, Jurnal Rekajiva 1(2).

Puslitbang Hasil Hutan, 2017, Laporan Ringkasan Penelitian, Buku II, Kementerian Lingkungan Hidup dan Kehutanan, Badan Penelitian, Pengembangan dan Inovasi, Pusat Penelitian dan Pengembangan Hasil Hutan, Bogor.

Rachman, O. \& Jasni, 2013, Rotan. Sumberdaya, sifat dan pengolahannya, Badan Penelitian dan Pengembangan Kehutanan, Jakarta.

Retraubun, A.S.W., 2013. Hilirisasi industri rotan menjadi komitmen utama kementerian Perindustrian, Furnicraf Today, Membangun Pertumbuhan Industri yang Terbesar di Kawasan Regional, Media informasi Industri Mebel dan Kerajinan Nasional, hal. 32-33.

Schreer, V., 2016. Learning knowledge about rattan (Calamoideae Arecaceae) and its uses amongst Ngaju Dayak in Indonesian Borneo. Journal of Ethnobiology, 36(1), 125-146.

Witono, J.R., Rustiami, H., Hadiah, J.T. \& Purnomo, D.W., 2013, Panduan lapangan pengenalan jenis rotan Katingan, WWF-Indonesia Program Kalimantan Tengah. 